\section{Géneros}

Multidisciplinary Journal of Gender: Studies

\section{Hipatia Press \\ www.hipatiapress.com}

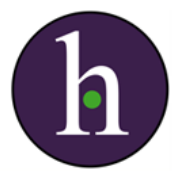

Instructions for authors, subscriptions and further details:

$\underline{\text { http://generos.hipatiapress.com }}$

\title{
Once a Criminal Always a Criminal? A 15-Year Analysis of Recidivism among Female Prisoners in Massachusetts
}

Mary Ellen Mastrorilli ${ }^{1}$

Maureen Norton-Hawk ${ }^{2}$

Nicole Usher ${ }^{2}$

1) Department of Applied Social Sciences, Boston University Metropolitan College

2) Department of Sociology, Suffolk University

Date of publication: October $25^{\text {th }}, 2015$

Edition period: October 2015 - February 2016

To cite this article: Mastrorilli, M.E.; Norton-Hawk, M. \& Usher, N. (2015). Once a Criminal Always a Criminal? A 15-Year Analysis of Recidivism Among Female Prisoners in Massachusetts. Multidisciplinary Journal of Gender Studies, 4(3), 784-805. doi: 10.4471/generos.2015.1545

To link this article: http://doi.org/10.4471/generos.2015.1545

\section{PLEASE SCROLL DOWN FOR ARTICLE}

The terms and conditions of use are related to the Open Journal System and to Creative Commons Attribution License (CC-BY). 


\section{Once a Criminal Always a Criminal? A 15-Year Analysis of Recidivism Among Female Prisoners in Massachusetts}

Mary Ellen Mastrorilli

Boston University
Maureen Norton-Hawk

Nicole Usher

Suffolk University

\section{Abstract}

The study of prisoner recidivism has long captured the interest of criminal justice researchers. Recidivism studies attempt to answer a variety of questions ranging from what are the characteristics of those who reoffend, what factors predict offender recidivism, and how long does a recidivist remain in the community before finding themselves in conflict with the law again. Unlike many studies that examine recidivism over a relatively short term - three to five years, this study investigates recidivism over a 15 -year period among a group of female offenders released from a Massachusetts prison in 1995. Findings point to three propositions moving forward. First, correctional programming geared specifically toward youthful offenders might be necessary to promote desistance over the life course. Second, offender monitoring and accountability up to 36 months after release from incarceration may reduce the risk of re-offending. Third, studies with a follow-up period of ten years would be a valuable addition to the recidivism literature to advance our understanding of chronic offending among women.

Keywords: female offenders, recidivism, offender reentry 


\section{¿Una Vez Se Es Criminal Siempre Se Es? Un Análisis de 15 Años sobre la Reincidencia de Mujeres Prisioneras en Massachusetts}

Mary Ellen Mastrorilli

Boston University
Maureen Norton-Hawk

Nicole Usher

Suffolk University

\section{Resumen}

El estudio de la reincidencia de los presos ha captado el interés de los investigadores de justicia penal durante mucho tiempo. Estudios sobre reincidencia intentan responder una serie de preguntas que van desde lo que son las características de los que reinciden, qué factores predicen la reincidencia delincuente, y cuánto tiempo una persona reincidente permanece en la comunidad antes de que se encuentre en conflicto con la ley de nuevo. A diferencia de muchos estudios que examinan la reincidencia en un plazo relativamente corto - tres a cinco años-, este estudio investiga la reincidencia en un período de 15 años entre un grupo de mujeres delincuentes liberadas de una prisión de Massachusetts en 1995. Los hallazgos apuntan a tres proposiciones. En primer lugar, podría ser necesaria la programación correccional orientada específicamente hacia las delincuentes juveniles para promover el desistimiento a largo de la vida. En segundo lugar, la supervisión y rendición de cuentas hasta 36 meses después de su liberación de la cárcel pueden reducir el riesgo de reincidencia. En tercer lugar, los estudios con un período de seguimiento de diez años, serían una valiosa aportación a la literatura sobre reincidencia para avanzar en nuestra comprensión de la delincuencia crónica entre las mujeres.

Palabras clave: mujeres delincuentes, reincidencia, reentrada delincuente

2015 Hipatia Press

ISSN: 2015-3613

doi: 10.4471/generos.2015.1545

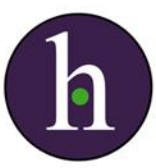


rime and punishment policy in the United States took a decidedly punitive turn in the early 1980's (Austin \& Irwin, 2011). The country's War on Drugs, first declared by President Nixon in 1971, and the ensuing installation of "drug czars," all but guaranteed an explosive growth in the country's correctional population (Gomila \& Hanser, 2012). Despite having only $5 \%$ of the world's population, the United States now incarcerates $25 \%$ of those who are imprisoned worldwide (American Civil Liberties Union, 2011). Over 1.6 million persons are currently incarcerated in American state and federal prisons, by far the world's highest imprisonment rate for both males and females (Carson \& Sabol, 2012; Walmsley, 2012; Walmsley, 2013). State spending on corrections has quadrupled over the past two decades, soaring to an estimated $\$ 51.4$ billion in 2012 (National Association of State Budget Officers, 2013).

Of the 1.6 million incarcerated individuals, $6.7 \%$ are female. While accounting for only a fraction of the total prison population, the number of female prisoners is growing at a faster rate than their male counterparts. State and federal prisons house over 113,000 women -- a 769\% percent increase from 1980 (Carson \& Golinelli, 2013). Only 13.9\% of the women under Federal jurisdiction and $36.6 \%$ of those in state facilities are serving sentences for a violent crime. The remainder is imprisoned primarily for drug and property offenses (Carson \& Sabol, 2012).

The stated goals of federal, state, and local prison systems include protection of the community and the re-integration of offenders as productive, law-abiding citizens. ${ }^{1}$ Over 600,000 prisoners were released in 2012 from the nation's state and federal prisons (Carson \& Golinelli, 2013), with the hope that they have been properly rehabilitated and will refrain from future criminal activity. However, it is unclear given the increasing length of sentences, crowded prison conditions, and decreases in funding for prisoner re-entry programs if rehabilitation and public safety are merely rhetorical assertions. Approximately $45 \%$ of prisoners re-offend within the first three years of their release (Pew Center on the States, 2011), providing strong evidence that the system is not accomplishing its' rehabilitative goals (Johnson, 2011; Selman \& Leighton, 2010). As states continue to face expanding prison costs, determining effectiveness of American criminal justice policies is essential for policy makers. 


\section{Previous Research}

\section{Female Recidivism}

Much of the literature on recidivism focuses on men or compares male and female recidivists. (Deschenes et al., 2007; Cobbina, 2010; Stuart \& BriceBaker, 2004; Uggen \& Kruttshnitt, 1998). Research focusing on women tends to have smaller samples (Maruna, 2001; Harm \& Phillips, 2001) and is often based on in-depth, qualitative analysis (Byrne \& Trew, 2008). Many of these studies have produced valuable insights but are limited in their ability to examine recidivism for a single cohort over time and to statistically analyze demographic factors associated with this group (Huebner et al., 2010). Recidivism is best viewed over longer periods of time, as it is a dynamic ongoing process (Bushway et al., 2001). Some releases will never exit the criminal world, others will conform to normative social standards, and a portion will engage in criminality sporadically. As noted by Huebner et al. (2010), "It is important to differentiate offenders who fail in short and long term and those who do not fail at all" (p. 233). The great majority of the current recidivism research analyzes recidivism over a relatively short term (1-5 years), considering the length of an individual's life span. One of the earliest studies to examine female recidivism was Sheldon and Eleanor Gluecks' classic 1930's research study, 500 Delinquent Women. They followed women imprisoned in the Massachusetts Reformatory for Women in Framingham for five years after their release. The researchers found a relationship between age, marital status, ethnicity, economic disadvantage, and criminal history (Glueck \& Glueck, 1934). The longest existing largescale longitudinal analysis of females post-incarceration was an 8 year follow-up study on parolees conducted by Huebner et al. (2010). They found that women characterized by drug dependence, extensive criminal histories, lack of education, and residing in a disadvantaged community were at greater risk to fail under parole supervision. The current study aims to identify predictive demographic variables associated with female prisoners released in Massachusetts over a substantially longer period of time - 15 years. Additionally, it fills a gap in the literature with regard to how long recidivism follow up periods should be in terms of assessing periods of desistance. 


\section{Demographic Variables Related to Recidivism}

Regarding age, female offenders are similar to their male counterparts. For instance, both men and women are less likely to reoffend as they get older (Deschenes et al., 2007; McIvor et al. 2011). Alternatively, youthfulness, in terms of age of the offender and age at first incarceration increase the likelihood of recidivism (Kruttschnitt \& Gartner, 2003; Stuart \& BriceBaker, 2004). Age has been shown to be in a robust inverse relationship with criminal behavior (Sweeten et al. 2013).

Less clear is the role that marriage and other pro-social bonds play as a predictive factor in female offender recidivism. There is a strong body of literature pointing to the inoculating effect that marriage has on criminal reoffending recidivism (Beaver et al., 2008; Giordano et al., 2002; Sampson \& Laub, 1993; Somers et al., 1994; Uggen \& Kruttschnitt, 1998). However, other researchers conclude that marriage and social relationships and networks have a complex relationship to recidivism and desistance. Forrest (2007), for example, finds that while marriage has a positive effect on desistance, cohabitation does not. It appears the effects of marriage on crime are mediated by the social orientation of the spouse as well as the quality of the relationship between the woman and her spouse.

The literature on race and recidivism is mixed. Deschenes et al.'s (2007) secondary analysis of the 2002 Bureau of Justice Statistics' three-year follow-up of post released female inmates from 15 states, found a variety of negative outcomes. More than half (57.6\%) were re-arrested, approximately $40 \%$ were re-convicted and almost a third (30.2\%) returned to prison with or without a new offense. African American women were the most likely to be re-arrested (63\%), re-convicted (43.8\%) and re-incarcerated (34\%). In a one year study of women released in 2010, Rautenberg and Matthews (2013) concluded that White/Caucasian women had the highest recidivism rate (19\%), followed by Hispanic women (16\%) and African American women (13\%), but found no significant relationship between race and female recidivism. In their meta-analysis of violent recidivism using demographics as predictors in 31 studies, Piquero, et al. (2015) found that age (young), sex (male) and race (white) were significantly related to violent reoffending. In Benda's (2005) 5-year follow up on male and female boot camp graduates, race was an insignificant predictor of male and female recidivism. Likewise, Huebner et al. (2010) in their 8-year study of 506 women released from 
prison in 1998 found that race did not reach a level of predictive significance relative to reoffending.

Researchers have found that offenders with a lengthy criminal history were more likely to re-offend (Kruttschnitt \& Gartner, 2003). Being young, lacking a pro-social network, failing to obtain meaningful employment, having an extensive criminal history, and abusing substances correlate to a high risk of recidivism (Huebner \& Berg, 2011; Laub \& Sampson, 2001; Tripodi, 2007; Tripodi et al., 2010). Huebner et al. (2010) concluded that women who have more serious criminal histories, are addicted to drugs, or are less educated are more likely to recidivate.

These previous findings on female offenders will be treated as testable hypotheses in the present study. Thus, the goals of the current study are to:

1. Describe the sample characteristics.

2. Examine recidivism in the fifteen years after release in 1995.

3. Identify characteristics significantly associated and predictive of recidivism.

4. Discuss optimal length of follow-up period in the analysis of recidivism.

\section{Methodology}

This research analyzed data describing 816 women released from MCIFramingham, the only committing institution for female offenders in Massachusetts. State and most county sentenced offenders and those awaiting trial are housed at this institution. ${ }^{2}$ All sentenced women released between January 1, 1995 and December 31, 1995 were included in the data set, resulting in a sample of 901 cases. Variables were limited to age, race, marital status, residential address, facility, and type of release. Recidivism was defined as the first commitment to a state or county correctional facility for a criminal offense or technical violation of probation or parole over a 15year follow up period.

After deleting duplications, the sample size was reduced to 839 women. Criminal history data were retrieved from the Massachusetts' Department of Criminal Justice Information Services. Due to the inability to access every "rap sheet," the resulting sample was reduced by 23, resulting in a total of 816 case records. After the two data bases were merged, a code was assigned to each case and personal identifying information was deleted. Approval to 
access human subjects records was gained from Suffolk University's I.R.B. and the Massachusetts Department of Correction. The investigators conducted descriptive, bivariate, and multivariate analyses using SPSS v.19.

\section{Statistical Analysis and Findings}

Univariate analysis was conducted to describe the characteristics of the sample of 816 women.

Table 1

Characteristics of the sample $(N=816)$

\begin{tabular}{lcc}
\hline & Frequency & Percent \\
\hline Race & & \\
White/Caucasian & 563 & 69.0 \\
African American & 132 & 16.2 \\
Hispanic & 115 & 14.1 \\
Other & 6 & .7 \\
Marital Status & & \\
Single & 585 & 71.1 \\
Ever Married & 231 & 28.3 \\
Town Type & & \\
Urban & 618 & 77.8 \\
Suburban & 144 & 18.1 \\
Rural & 32 & 4.0 \\
Gateway City Residents & 405 & 49.6 \\
Worcester & 125 & 15.3 \\
Lynn & 71 & 8.7 \\
Boston & 62 & 7.6 \\
Lowell & 57 & 7.0 \\
Brockton & 46 & 5.6 \\
Lawrence & 44 & 5.4 \\
\hline
\end{tabular}

The women released in 1995 ranged in age from 17 to 70, with a median age of 32 years. Sixty-nine percent of the women were White/Caucasian, 16\% African American, 14\% Hispanic, and 0.7\% other. Seventy-one percent of the women were single. Most of the women resided in urban areas. Fifty percent of the women came from one of six towns, which have been labelled 
"gateway cities" (Gateway Cities Innovation Institute, 2007). These six cities have a low per capita income, a high percent of people living below the poverty line, and a large percent of non-white and foreign born citizens when compared to the state average (U.S. Census). ${ }^{3}$ Although Boston's unemployment rate is only $5.9 \%$, the women in this sample came disproportionately from neighbourhoods of concentrated poverty.

The criminal history descriptors of the study sample show a largely nonviolent population.

Table 2

Criminal history of the sample $(N=816)$

\begin{tabular}{|c|c|c|}
\hline & Frequency & Percent \\
\hline \multicolumn{3}{|l|}{ Institution of Release } \\
\hline Framingham & 663 & 81.3 \\
\hline Other & 153 & 18.8 \\
\hline \multicolumn{3}{|l|}{ Parole } \\
\hline Yes & 213 & 26.1 \\
\hline No & 603 & 73.9 \\
\hline \multicolumn{3}{|l|}{ Crime Committed } \\
\hline Drugs & 199 & 24.4 \\
\hline Morals & 157 & 19.2 \\
\hline Motor Vehicle & 115 & 14.1 \\
\hline Other & 20 & 2.5 \\
\hline Person & 103 & 12.6 \\
\hline Property & 216 & 26.5 \\
\hline Sex & 2 & .2 \\
\hline \multirow[t]{2}{*}{ Weapon } & 4 & .5 \\
\hline & Median & Age Range \\
\hline Age at First Arraignment & 21 & $14-67$ \\
\hline Age at First Incarceration & 24 & $14-69$ \\
\hline Age at First Conviction & 29 & $17-69$ \\
\hline
\end{tabular}

Property offenses (27\%) and drug violations (24\%) accounted for more than half of the women's governing offenses; while only $12 \%$ were convicted of violent crimes. Four fifths of the women were released from Framingham State Prison (81\%). The remaining $19 \%$ exited one of 
Massachusetts' pre-release or minimum security facilities. Of these totals, only $26 \%$ were released on parole. The parole statistic is somewhat unexpected given the non-violent nature of the offending. The median age of first arraignment was 21, first conviction 24, and first incarceration 29. Ages of first involvement ranged from 14-67 years (first arraignment), 14-69 years (first conviction) and 17-69 years (first incarceration). Women were equally likely to have a minor/moderate $(48 \%)$ or serious/repetitive $(52 \%)$ criminal histories according to the Massachusetts Criminal History Scale. This instrument categorizes criminal history by using two factors -- severity of offense levels ranging from 1 to 9, and number of offenses. For example, a Level 9 offense would be murder and a Level 1 offense would be vandalism. A moderate record would consist of six or more prior convictions for a Level 1 or 2 offense.

Of the sample of 816 women, more than half $(52.8 \%)$ returned to prison at least once before 2010. Return to prison occurred soon after release. Of the 431 who were re-incarcerated, 220 (53\%) were re-committed within the first 2 years after release. By the 4th year, $70 \%$ had been re-incarcerated. The median number of days before re-incarceration for a County sentenced woman was 688 while State sentenced women remained in the community 1301 days. Taken together, there are several interesting findings here. The first three years after release are clearly the most at-risk period for criminal reoffending. More than $2 / 3$ of the women in the sample were reincarcerated within 36 months. Secondly, a substantial number of women continued their criminal offending up to ten years post release. By year 11, the numbers drop off into the single digits. This finding suggests that researchers might consider using a follow-up period of 10 years when studying recidivism to better understand the factors that contribute to recidivism so far out from release. The finding begs the question - are the offenders who are quick to reoffend different than those who are not and if so, how and why. 


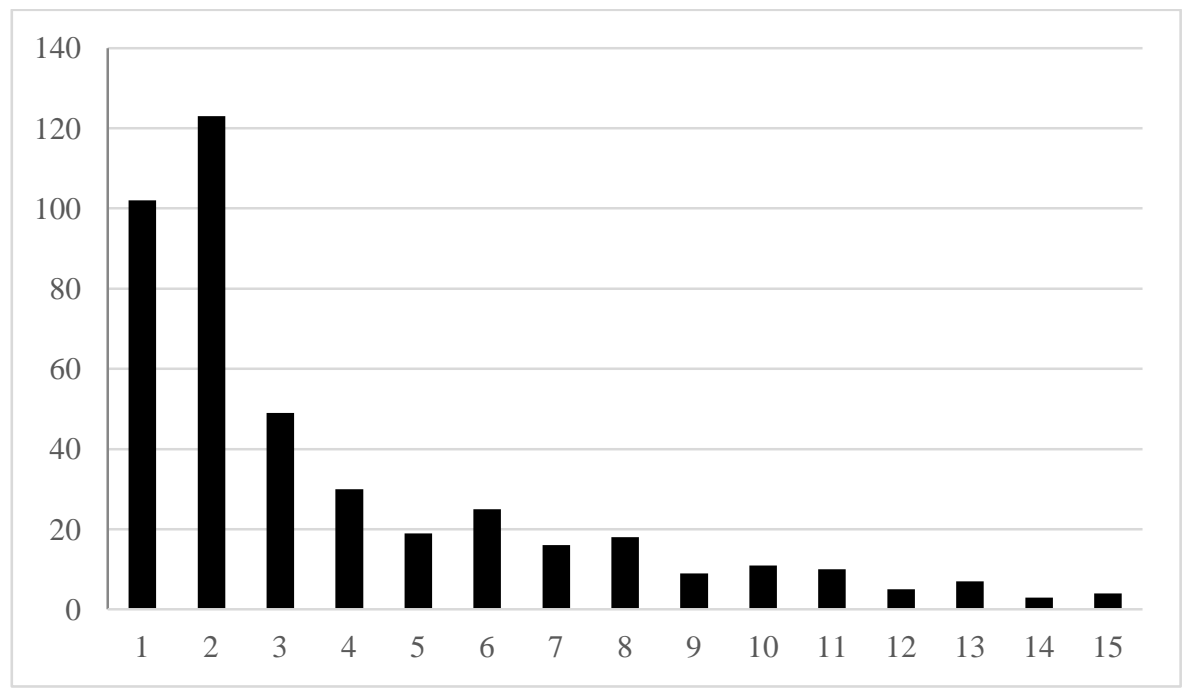

Figure 1. Number of Women Re-Incarcerated by Year Post-Release 1995 n=431

The majority of those who were re-incarcerated (414 out of 431) received a county sentence (i.e. 2.5 years or less). Only 17 received a state prison sentence, indicative of a conviction of a serious crime or criminal record. Taking a conservative analytic approach, given the small number of women sentenced to state prison could alter the representativeness of the sample, this group was excluded from the bivariate analysis.

\section{Bivariate Analysis}

Bivariate analysis was used to determine the relationship between the dependent variable, recidivism, and nine independent variables to determine if the study sample was reflective of national trends. Recidivism was coded as 0 (not re-incarcerated) and 1 (re-incarcerated). Because the following variables have been identified in the literature as having a relationship to recidivism they were used as independent variables in this analysis: age, race, marital status, city type, type of release, institution of release, offense type, and age of first involvement in the criminal justice system. Recidivists and non-recidivists were similar in the following categories - marital status, i.e. single/never married, resident of an urban community, and race. 
Table 3

Demographic characteristics: Re-incarcerated house of corrections $v$. not reincarcerated

\begin{tabular}{|c|c|c|c|c|}
\hline & \multicolumn{2}{|c|}{$\begin{array}{c}\text { Re-incarcerated HOC } \\
\text { N=414 }\end{array}$} & \multicolumn{2}{|c|}{$\begin{array}{c}\text { Not Re-incarcerated } \\
\qquad \mathrm{N}=385\end{array}$} \\
\hline & Frequency & Percent & Frequency & Percent \\
\hline \multicolumn{5}{|l|}{ Race } \\
\hline White/Caucasian & 291 & $70.6(52.2)$ & 266 & $69.8(47.2)$ \\
\hline African American & 67 & $16.3(54.0)$ & 57 & $15.0(43.2)$ \\
\hline Hispanic & 54 & $13.1(48.2)$ & 58 & $15.2(50.4)$ \\
\hline \multicolumn{5}{|l|}{ Marital Status } \\
\hline Single & 299 & 72.2 & 272 & 70.6 \\
\hline Ever married & 115 & 27.8 & 113 & 29.4 \\
\hline \multicolumn{5}{|l|}{ Town Type } \\
\hline Urban/City & 315 & 77.2 & 289 & 78.3 \\
\hline Suburban & 75 & 18.4 & 67 & 18.2 \\
\hline Rural & 18 & 4.4 & 13 & 3.5 \\
\hline \multicolumn{5}{|l|}{ Gateway City } \\
\hline Yes & 200 & 48.3 & 198 & 51.4 \\
\hline No & 214 & 51.7 & 187 & 48.6 \\
\hline Median Age ${ }^{* * *}$ & 31 & & 34 & \\
\hline
\end{tabular}

$* \mathrm{p}<.01 * * \mathrm{p}<.001 * * * \mathrm{p}<.000$

The governing offenses for both recidivists and non-recidivists are similar with one exception. Recidivists were more likely to have been serving time for a morals offenses (e.g. common night walking, lewd behaviour, sex for a fee, and solicitation). This finding is not unusual given the typology of the street prostitute - someone who sells sexual services often in support of an illicit drug addiction (Romero-Daza, et al. 2010). Similarly, when examining the crimes the recidivists committed that resulted in their reincarceration, $27 \%$ were drug, $26 \%$ were morals, and $21 \%$ were property offenses. Less than $10 \%$ of the reincarcertive governing offenses were related to violence, weapons, or sex. 
Table 4

Subsequent criminal offenses of recidivists

\begin{tabular}{lcc}
\hline & Frequency & Percent \\
\hline Morals & 112 & 27.1 \\
Drug & 108 & 26.1 \\
Property & 86 & 20.8 \\
Motor Vehicle & 46 & 11.1 \\
Person & 35 & 8.5 \\
Other & 24 & 5.8 \\
Sex & 2 & .5 \\
Weapon & 1 & .2 \\
\hline Total & 414 & 100.0 \\
\hline
\end{tabular}

\section{Statistically Significant Findings}

As Kruttschnitt and Gartner (2003) had previously found, younger women were significantly more likely to be re-incarcerated $(\mathrm{p}<.001)$. This held true in the present study. Of women 17 to 30 years of age, $44 \%$ were reincarcerated, while only $36 \%$ in that same age range were re-committed to prison. The difference between the age of the women rose to the level of significance $(\mathrm{p}<.001)$. The median age for re-incarceration was 31 compared to 34 for those who stayed out of prison.

As seen in Table 6, age of first arraignment, first conviction and first incarceration were significantly associated $(\mathrm{p}<.001)$ with re-incarceration. Of the women who were 19 years or younger at arraignment, $46 \%$ were reincarcerated compared to $30 \%$ not re-incarcerated. This relationship was similar for age at first conviction 19 years or less (27\% vs. 14\%) and first incarceration 19 years or younger (11\% vs. 4\%). Median age of first arraignment was 20, first conviction age 23 and first incarceration age 27 compared to 23, 27 and 31 years for those who did not return to prison after release. As previously reported by Huebner et al. (2010), extensive involvement with the criminal justice system was significantly associated with re-incarceration. As the number of lifetime arraignments, convictions and incarcerations increased, the percent of women who were reincarcerated also increased $(\mathrm{p}<.001)$. This relationship can also be observed using the Massachusetts Department of Correction categorization 
of criminal history, which ranks criminal behaviour history on a scale of 1 to 6. Fifty-seven percent of the women who were assessed as having a serious/repetitive criminal history returned to prison $(\mathrm{p}<.001)$.

Table 5

Criminal history: Re-incarcerated house of corrections v. not re-incarcerated

$\begin{array}{cc}\text { Re-incarcerated HOC } & \text { Not Re-incarcerated } \\ \mathrm{N}=414 & \mathrm{~N}=385\end{array}$

Frequency Percent Frequency Percent

\section{Institution of}

Release $^{* * *}$

Framingham
357

Other

57
86.2

323

No

\section{Offense Original}

Drug

Morals

Motor Vehicle

Other

Person

Property

Sex

Weapon

Offense Re-

incarceration

Drug

Morals

Motor Vehicle

Other

Person

Property

Sex

Weapon
13.8

91

22.0

115

29.9

78.0

270

70.1

93

22.5

101

26.2

92

22.2

64

16.6

47

11.4

67

17.4

12

2.9

12.6

7

1.8

52

117

0

28.3

0

.2

48

12.5

94

24.4

1

1

.3

3 
795 Mastrorilli, Norton-Hawk \& Usher-Female Prisoners

\begin{tabular}{|c|c|c|c|c|}
\hline & \multicolumn{2}{|c|}{$\mathrm{N}=414$} & \multicolumn{2}{|c|}{$\mathrm{N}=385$} \\
\hline & Frequency & Percent & Frequency & Percent \\
\hline \multicolumn{5}{|l|}{ Criminal History** } \\
\hline None/minor/moderate & 177 & 42.8 & 212 & 55.1 \\
\hline Serious/violent/repetitive & 237 & 57.2 & 173 & 44.9 \\
\hline \multicolumn{5}{|l|}{ Age at $1^{\text {st }}$} \\
\hline \multicolumn{5}{|l|}{ Arraignment $* * *$} \\
\hline 19 or less & 191 & 46.1 & 114 & 29.6 \\
\hline $20-29$ & 179 & 43.2 & 175 & 45.5 \\
\hline $30+$ & 44 & 10.6 & 96 & 24.9 \\
\hline \multicolumn{5}{|l|}{ Age at $1^{\text {st }}$} \\
\hline \multicolumn{5}{|l|}{ Conviction*** } \\
\hline 19 or less & 112 & 27.1 & 55 & 14.3 \\
\hline $20-29$ & 225 & 54.3 & 180 & 46.8 \\
\hline $30+$ & 77 & 18.6 & 150 & 39.0 \\
\hline \multicolumn{5}{|l|}{ Age at $1^{\text {st }}$} \\
\hline \multicolumn{5}{|l|}{ Incarceration $* * *$} \\
\hline 19 or less & 45 & 10.9 & 17 & 4.4 \\
\hline $20-29$ & 217 & 52.4 & 145 & 37.7 \\
\hline $30+$ & 152 & 36.7 & 223 & 57.9 \\
\hline $\begin{array}{l}* \mathrm{p}<.01 * * \mathrm{p}<.001 \\
* * * \mathrm{P}<.000\end{array}$ & & & & \\
\hline
\end{tabular}

Re-incarceration was strongly associated with the institution of release ( $<<.001)$. Only 14\% of the re-incarcerated women had been released from a pre-release facility compared to almost double the percent of women who were not re-incarcerated $(24 \%)$.

Release on parole was significantly associated with not being reincarcerated $(\mathrm{p}<.01)$. Thirty percent of those who were not re-incarcerated were released on parole compared to $22 \%$ of women who were reincarcerated were not on parole at the time of discharge. 


\section{Multivariate Analysis}

A logistic regression analysis was conducted to predict recidivism in the 15 year post release period. Purposeful selection of variables for the logistic regression model was based on the Pearson's Chi Square test indicating significant association. Independent variables that attained a significance level of $\mathrm{p}<.05$ were included in the model. Therefore, the variables listed in Table 7 were selected to test their predictive power. As previously noted, the dependent variable, recidivism, was coded 0 (not re-incarcerated) and 1 (re-incarcerated).

Table 6

Independent variables in the logistic regression model

\begin{tabular}{lll}
\hline & \multicolumn{1}{c}{$\mathbf{0}$} & \multicolumn{1}{c}{$\mathbf{1}$} \\
\hline $\begin{array}{l}\text { Criminal history } \\
\begin{array}{l}\text { Age } \mathbf{1}^{\text {st }} \\
\text { arraignment }\end{array}\end{array}$ & $\begin{array}{l}\text { None, minor, moderate } \\
\text { Twenty years plus }\end{array}$ & $\begin{array}{l}\text { Serious, violent, repetitive } \\
19 \text { years or younger }\end{array}$ \\
$\begin{array}{l}\text { Release institution } \\
\text { Age at release }\end{array}$ & $\begin{array}{l}\text { Not Framingham } \\
\text { Continuous }\end{array}$ & Framingham \\
\hline
\end{tabular}

A test of the full model against a constant found that release institution, criminal history, age of first arraignment and age at release made a significant contribution to prediction of recidivism. A woman released from Framingham, compared to release from a minimum security facility or parole, was 1.9 times more likely to be re-incarcerated. Post-release women with a serious/repetitive criminal history were 1.6 times more likely to return to prison during the 15 years post incarceration. Released women who had their first arraignment before the age of 19 were also 1.6 times more likely to be recidivists. Finally, for every year increase in age, the re-incarceration rate decreased by $3.9 \%$ as seen in Table 8 . 
Table 7

Statistically significant variables

\begin{tabular}{llll}
\hline & $\mathbf{B}$ & Significance & $\operatorname{Exp}(\mathbf{B})$ \\
\hline Release Institution & $.665(.270)^{*}$ & .001 & 1.945 \\
Criminal History & $.520(.159)^{*}$ & .001 & 1.682 \\
Age 1 & $.499(.166)^{*}$ & .002 & 1.647 \\
Arraignment & & & \\
Age at release & $-.039(.012)^{*}$ & .003 & .962 \\
-2 Log likelihood & 1050.583 & & \\
Model chi sq & 5.234 & & \\
\hline
\end{tabular}

*standard error

\section{Discussion}

This study provides additional evidence to the literature that race of the offender is not significantly associated with female recidivism. Furthermore, female offender racial disparities are decreasing in the rates of incarceration both in Massachusetts and nationally. According to the Massachusetts Department of Correction Inmate Statistics, in 1997 the female prison population as of January $1^{\text {st }}$ was $53 \%$ White/Caucasian, 22\% African American and 24\% Hispanic (Sampson et al., 1999). The racial breakdown was vastly different in 2009, with White/Caucasian women showing a $10 \%$ increase to $64 \%$ and African American and Hispanic women dropping to $16 \%$ and $15 \%$ respectively (Research and Planning Division, 2009). As the racial proportions change, differences would lessen so that significant racial disparities would be less detectable. Nationally, a similar pattern is emerging. Between 2000 and 2009, the rate of incarceration for African American women declined by $31 \%$ while increasing $47 \%$ for White/Caucasian women and 23\% for Hispanic women (Mauer, 2013).

Unexpectedly, a women's residential address did not rise to the level of statistical significance. Researchers have argued that people from socially marginalized and disadvantaged neighbourhoods are more likely to be involved in crime thus more likely to find themselves incarcerated (Sampson \& Raudenbush, 2001; Kubrin \& Steward, 2006). Urban versus suburban post-release women in this study were equally likely to be re-incarcerated. Additionally, women living in "Gateway Cities" (those locations with 
concentrated low employment, high poverty rates and racially/ethnically diverse populations), might be expected to be involved in long-term criminal behaviour. In fact, the study found women from these neighbourhoods were slightly less likely to recidivate. Without additional contextual data it is difficult to surmise why this might be the case.

Previous studies have indicated that age at release predicts recidivism (Deschenes et al., 2007; Stuart \& Brice- Baker, 2004; Kruttschnitt \& Gartner, 2003). As women age, recidivism rates decline. This study is in accord with the age/crime curve, which indicates that criminal involvement increases throughout the adolescent years and then declines as one ages (Shulman et al., 2013; Gottfredson \& Hirschi, 1990). By 18 years of age, $25.6 \%$ of the women in this study had been arraigned, $12.9 \%$ had at least one conviction and $4.9 \%$ had been incarcerated. Those who become involved at a very young age are likely to accumulate numerous arraignments, convictions and incarcerations over their lifetime. For some young offenders, early involvement may indicate delinquent tendencies that are immutable. For others, it may be that juveniles who are socialized in a correctional environment may find it difficult to comply with normative, prosocial standard (Stuart \& Brice-Baker, 2004). Age of the offender continues to remain a predictive risk factor. The consistency of the relationship between age and crime argues for the development of correctional programming geared specifically toward the youthful offender who, in the eyes of the criminal justice system, is an adult but developmentally still very much a child in need of structure, mentoring, and the acquisition of basic life skills.

The most severe risk period for women's recidivism occurs shortly after release. Those on parole were significantly less likely to be re-committed, suggesting that community support and monitoring might be useful during this vulnerable period. Parole release increases the likelihood of return to prison due to technical violations, but when parole violations are excluded from the analysis it appears that requiring accountability for one's behaviour for a period of time may be warranted. Due to the high cost of incarceration, many states have reconsidered regulations that routine commit parole violators. Louisiana restricts the amount of time for which a person can be re-incarcerated for a parole violation. Oregon, Nevada, California and West Virginia are examples of states that offer staggered sanctions that may 
include community service options. Colorado and Tennessee have created specialized violator facilities in lieu of returning some parole violators to prison (Lawrence, 2008).

If mandated parole or increased parole rates are not an option, pre-release facilities and community-based programs should be made more available. We found women released from a pre-release facility were significantly less likely to be re-incarcerated. Studies have indicated that preparation for reintegration into mainstream society reduces recidivism as return to society can present major familial, financial and emotional hurdles (Griffin \& Armstrong, 2003; Petersilia, 2003; Shand, 1996; Travis, 2005). Easing these transitional challenges through pre-release programs might increase the likelihood that a woman will stay out of the criminal justice system altogether or for a longer period of time.

Lastly, this study advances the proposition that recidivism follow up periods of three to five are short-sighted. In this sample of female prisoners, $70 \%$ recidivated after four years. While the literature tells us why some offenders are vulnerable shortly after release -- returning to impoverished, crime-ridden neighbourhoods (Sampson \& Raudenbush, 2001; Kubrin \& Steward, 2006); relapsing after a period of imposed sobriety; leaving facilities without adequate re-entry plans), what might propel a women into becoming a recidivist if she has been living crime free for 8,10 , or 15 years? Studies that examine this phenomenon will fill an important gap in our knowledge of criminal re-offending.

\section{Study Limitations}

This study is not without its limitations. First, the researchers were constrained by the lack of accessibility to contextual prisoner data, such as family bonds, employment and educational history, and substance use. Information about the criminal history and demographics of the sample provided us only a narrow examination of recidivism that was largely descriptive. Without rich detail into the familial and psycho-social lives of the women in this sample, we can only speculate about their pathways into and more importantly, out of crime.

Secondly, this study could deeply benefit from an analysis of multiple reentries into the justice system. We know that some women in the sample 


\section{GÉNEROS -Multidisciplinary Journal of Gender Studies, 4(3) 800}

recidivated more than once over the 15-year follow up period, but due to time and budgetary constraints of the project, this analysis was not possible. Tracking this movement could add to our knowledge about repetitive recidivism and the characteristics of the female habitual offender.

Third, our findings cannot be generalized beyond the female offender population in Massachusetts. Our sample was comprised of a cohort of women who were released from a Massachusetts prison in 1995.

\section{Notes}

1 "It is the mission of the Federal Bureau of Prisons to protect society by confining offenders in the controlled environments of prisons and community-based facilities that are safe, humane, cost-efficient, and appropriately secure, and that provide work and other selfimprovement opportunities to assist offenders in becoming law-abiding citizens" (http://www.bop.gov/about/mission.jsp). MA DOC Mission Statement: "Our mission is to promote public safety by managing offenders while providing care and appropriate programming in preparation for successful reentry into the community" (http://www.mass.gov/eopss/agencies/doc/).

${ }^{2}$ Massachusetts operates a bifurcated correctional system. Houses of Correction are managed by elected Sheriffs, are county-based, and house detainees awaiting trial and prisoners with sentences of 2.5 years or less. However, only 3 out of 14 county systems have facilities that house women. As a result, most county-sentences female prisoners serve time at the state institution for women.

${ }^{3}$ With the exception of Boston and Lynn these cities were identified as "Gateway Cities" in 2008. These "gateway cities" traditionally have been populated by foreign workers as jobs were available in the once economically vibrant manufacturing sector. As America has moved to a knowledge based economy job opportunities for unskilled immigrant labor declined leaving many individuals with few legitimate employment options (Forman et al, 2007). Fewer jobs means less taxable income which impacts social agencies, structural repairs, and community maintenance often leading to a general state of decline.

\section{References}

American Civil Liberties Union. (2011). Annual Review. New York, NY. p.19. Retrieved from

https://www.aclu.org/files/assets/2011_aclu_annual_review_-_web.pdf

Austin, J., \& Irwin, J. (2011). It's about time: America's imprisonment binge. Connecticut: Cengage Learning.

Beaver, K.M., Wright, J.P., DeLisi, M., \& Vaughn, M.G. (2008). Desistance from Delinquency: The marriage effect revisited and extended. Social Science Research, 37(3), 736-752. 
Benda, B. (2005). Gender differences in life-course theory of recidivism: A survival analysis. Internal Journal of Offender Therapy and Comparative Criminology, 49, 325-344. doi: 10.1177/0306624X04271194

Bender, K., Tripodi, S., Aguilar, J., \& Thompson, S. (2010). Predicting arrest in early adulthood: The relationship between internal and external sources of control. Social Work Research, 34(1), 58-64. doi: 10.1093/swr/34.1.58

Bushway, S.D., Piquero, A.R., Broidy, L.M., Cauffman, E., \& Mazerolle, P. (2001). An empirical framework for studying desistance as a process. Criminology, 39(2), 491-515. doi: 10.1111/j.17459125.2001.tb00931.x

Byrne, C.F. \& Trew, K.J. (2008). Pathways through crime: The development of crime and desistance in the accounts of men and women offenders. The Howard Journal of Criminal Justice, 47(3), 238-258. doi:

10.1111/j.1468-2311.2008.00520.x

Carson, E.A. \& Sabol, W.J. (2012). Prisoners in 2011 (87). United States Department of Justice. Bureau Justice Statistics. (NCJ239808). Washington, D.C.

Carson, E.A. \& Golinelli, D. (2013). Prisoners in 2012: Trends in admissions and releases 1991-2011. United States Department of Justice. Bureau Justice Statistics. (NCJ243920). Washington, D.C.

Cobbina, J.E. (2010). Reintegration success and failure: Factors impacting reintegration among incarcerated and formerly incarcerated women. Journal of Offender Rehabilitation, 49(3), 210-232. doi: 10.1080/10509671003666602

Deschenes, E.P., Owen, B., \& Crow, J. (2007). Recidivism among female prisoners: Secondary analysis of the 1994 Bureau of Justice Statistics recidivism data set. Long Beach, $\mathrm{CA}$.

Forrest, W. (2007). Adult family relationships and desistance from crime. (Unpublished doctoral dissertation). Florida State University, Tallahassee, FL.

Gateway Cities Innovation Institute. (2007). Retrieved from

http://www.massinc.org/programs/gateway- cities.aspx

Giordano, P.C., Cernkovich, S.A., \& Rudolph, J.L. (2002). Gender, crime, and desistance: Toward a theory of cognitive transformation. American Journal of Sociology, 107(4), 990-1064. doi: 10.1086/343191 
Glueck, S. \& Glueck, E. (1934). Five hundred delinquent women. New York: Alfred A. Knopf.

Gottfredson, M.R. \& Hirschi, T. (1990). A general theory of crime. Stanford: Stanford University Press.

Gomila, M.N. \& Hanser, R.D. (2012). The war on drugs: A review of U.S. drug policy. In Reddington \& Bonham (Eds.), Flawed criminal justice policies (pp. 21-37). NC: Carolina Press.

Griffin, M.L. \& Armstrong, G.S. (2003). The effect of local life circumstance on female probationers' offending. JQ: Justice Quarterly, 20(2), 213-239. doi: 10.1080/07418820300095511

Harm, N.J. \& Phillips, S.D. (2001). You can't go home again: Women and criminal recidivism. Journal of Offender Rehabilitation, 32(3), 3-21. doi: 10.1300/J076v32n03_02

Huebner, B.M. \& Berg, M.T. (2011). Examining the sources of variation in risk for recidivism. JQ: Justice Quarterly, 28(1), 146-173. doi:

10.1080/07418820903365213

Huebner, B.M., Dejong, C., \& Cobbina, J. (2010). Women coming home: Long-term patterns of recidivism. JC: Justice Quarterly, 27(2), 225-254. doi: 10.1080/07418820902870486

Johnson, K. April 13, 2011. Study: Prisons failing to deter repeat criminals in 41 states. U.S.A. Today. Retrieved from http://usatoday30.usatoday.com/news/nation/2011-04-12-Prisonrecidivism-rates-hold-steady.htm

Kruttschnitt, C. \& Gartner, R. (2003). Women's imprisonment. In Tonry (Ed.), Crime and justice: A review of research (Vol. 30, pp. 1-82). Chicago, IL: University of Chicago Press.

Kubrin, C.E. \& Stewart, E.A. (2006). Predicting who reoffends: The neglected role of neighborhood context in recidivism studies. Criminology, 44(1), 165-197. doi: 10.1111/j.17459125.2006.00046.x

Laub, J.H. \& Sampson, R.F. (2001). Understanding desistance from crime. In Tonry \& Morris (Eds.), Crime and justice (Vol. 28, pp. 1-69). Chicago, IL: University of Chicago Press.

Lawrence, A. (2008). Probation and parole violations: State responses. National Conference of State Legislatures. Washington, D.C. 1-12 
Maruna, S. (2001). Making good: How ex-convicts reform and rebuild their lives. Washington, D.C.: American Psychological Association.

Massachusetts Criminal History Scale. Retrieved from

http://www.mass.gov/courts/court-info/trial-court/sent-

commission/criminal-history- groups-ma-sentencing-guidelinesgen.html

Massachusetts Department of Corrections (2011). Annual Report. Retrieved from http://www.mass.gov/eopss/docs/doc/annual-report-2011-final-0801-12.pdf

Mauer, M. (2013). Changing racial dynamics of women's incarceration. The Sentencing Project. Washington D.C.

McIvor, G., Murray, C., \& Jamieson, J. (2011). Desistance from crime: Is it different for women and girls? In Maruna \& Immarigeon (Eds.). After crime and punishment: Pathways to offender reintegration. (181-197). New York: Routledge.

National Association of State Budget Officers. (2013). Examining fiscal state spending fiscal 2011-2013 (pp. 51). Washington D.C.

Petersilia, J. (2003). When prisoners come home: Parole and prisoner reentry. New York, N.Y.: Oxford University Press.

Pew Center on the States. (2011). State of recidivism: The revolving door of America's prisons. Washington, D.C: The Pew Charitable Trusts, April.

Rautenberg, K., \& Matthews, H. (2013). 2010 release cohort one year recidivism statistics. Massachusetts Executive Office of Public Safety. Department of Corrections. October.

Research and Planning Division. (2009). January 1, 2009 inmate statistics (457). Massachusetts Executive Office of Public Safety and Security. Department of Corrections. (Pub. No. 09-149-DOC-01).

Romero-Daza, N., Weeks, M., \& Singer, M. (2003). Nobody gives a damn if I live or die: violence, drugs, and street-level prostitution. Medical Anthropology, 22(3), 233-259. doi: 10.1080/01459740306770

Sampson, R.J., \& Laub, J.H. (1993). Crime in the making: Pathways and turning points through life. Massachusetts: Harvard University Press.

Sampson, R.J. \& Raudenbush, S.W. (2001). Disorder in urban neighborhoods does it lead to crime? Research in Brief. National Institute of Justice Office of Justice Programs. (NCJ 186049). 
Sampson, L.L., Kaufman, C., \& Hartwell, B.A. (1999). January 1, 1997 inmate statistics (402). Massachusetts Executive Office of Public Safety and Security. Department of Corrections. (Pub. No. 18065-42-100).

Selman, D., \& Leighton, P. (2010). Punishment for sale: Private prisons, big business and the incarceration binge. New York: Rowman \& Littlefield.

Shand, R.S. (1996). Pre-release/transition: Inmate programs and support upon entry, during incarceration, and after release. Journal of Correctional Education, 47(1), 20-40.

Shulman, E.P., Steinberg, L.D., \& Piquero, A.R. (2013). The age-crime curve in adolescence and early adulthood due to age differences in economic status. Journal of Youth and Adolescence, 42(6), 848-860. doi: 10.1007/s10964-013-9950-4

Somers, I., Baskin, D.R., \& Fagan, J. (1994). Getting out of the life: Crime desistance by female street offenders. Deviant Behavior, 15(2), 125-149. doi: 10.1016/j.drugpo.2012.04.002

Stuart, B. \& Brice-Baker, J. (2004). Correlates of higher rate of recidivism in female prisoners: An exploratory study. Journal of Psychiatry and Law, 32(1), 29-70.

Sweeten, G., Piquero, A. \& Steinberg, L. (2013). Age and the explanation of crime, revisited. Journal of Youth and Adolescence, 42(6), 921-938. doi: 10.1007/s10964-013-9926-4

Tripodi, S.J. (presented 2007, November). Attachment to social bonds and its influence of recidivism for adult offenders. Presentation at Research That Matters, Florida State University College of Social Work, Tallahassee, FL. (Local).

Tripodi, S.J., Kim, J.S., \& Bender, K. (2010). Is employment associated with reduced recidivism? The complex relationship between employment and crime. International Journal of Offender Therapy and Comparative Criminology, 54(5), 706-720. doi: 10.1177/0306624X09342980

Travis, J. (2005). But they all come back: Facing the challenges of prisoner re-entry. Washington, D.C.: Urban Institute Press.

Uggen, C. \& Kruttschnitt, C. (1998). Crime in the breaking: Gender differences in desistance. Law \& Society Review, 32(2), 339-366.

Walmsley, R. (2012). World female imprisonment list (2). International Centre for Prison Studies. United Kingdom: London. Retrieved February 20, 2014 from http://www.prisonstudies.org/publications.html 
Walmsley, R. (2013). World prison population list (10). International Centre for Prison Studies. United Kingdom: London. Retrieved February 20, 2014 from http://www.prisonstudies.org/publications.html

Mary Ellen Mastrorilli Assistant Professor and Associate Chair, Department of Applied Social Sciences, Boston University Metropolitan College

Maureen Norton-Hawk Professor, Department of Sociology, Suffolk University

Nicole Usher Suffolk University

Contact address: Department of Sociology, Suffolk University, Rm. 581, 73 Tremont Street, Boston, MA 02108

E-mail address: mnhawk@suffolk.edu 